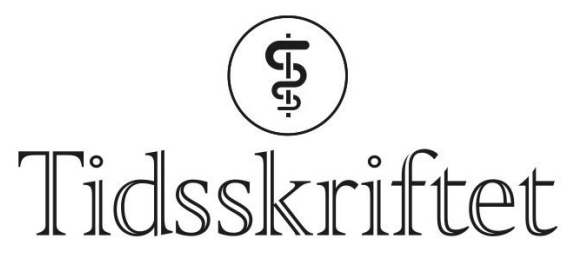

DEN NORSKE LEGEFORENING

\title{
Fra Sørlandet til sørlige Afrika
}

INTERVJU

MARIT TVEITO

E-post: marit.tveito@aldringoghelse.no

Nasjonal kompetansetjeneste for aldring og helse

Smittevernoverlege Tore Steen har jobbet med tuberkulose i Botswana og meslingutbrudd i Oslo. Men til syvende og sist lengter den jordnære sørlendingen alltid til nordnorske fjelltopper med og uten snø på.

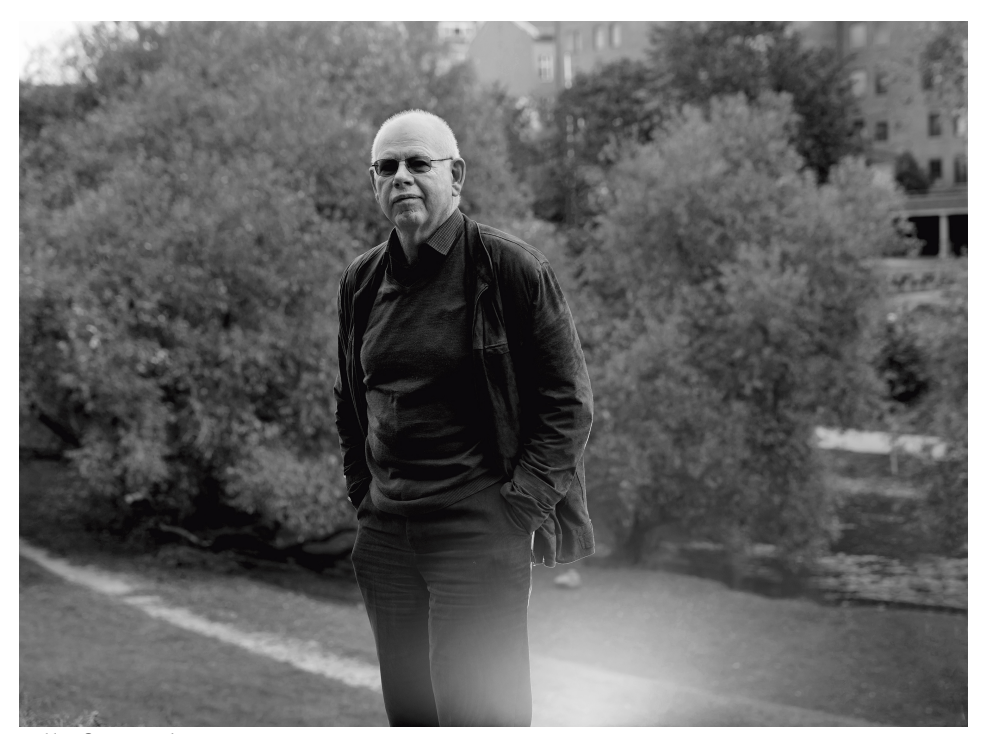

Alle foto: Christian Tunge

- Jeg har vært portrettintervjuet én gang før, forteller Steen.

- Det var i Fædrelandsvennen. De ville gjøre et intervju med flere om temaet tro og tvil, hvor jeg skulle representere middelveien. Det er 50 år siden nå.

De bløte konsonantene fra oppveksten sitter fortsatt og er kanskje med på å understreke inntrykket av Steen som en mild og rolig samfunnsmedisiner. Han uttaler seg om kontroversielle tema som obligatorisk vaksinasjon med en sindighet som står i kontrast til de sterke meningene som gjør seg gjeldende i «vaksinelandskapet». Kolleger beskriver ham som en grundig, flink, ujålete og beskjeden lege, som er lett å be og som får gjort mye. Han er ingen atlet, men heller en «seig traver» som kommer seg opp på de høyeste toppene. Det skal mye til før en planlagt fisketur, skitur eller fjelltur ikke blir noe av.

\section{Ung pasient}

Det aktive livet lå ikke i kortene da han seks år gammel fikk Calvé-Legg-Perthes’ syndrom, en 
sykdom hvor nedsatt blodforsyning til lårbeinshodet gjør at det delvis kan smuldre opp før nytt bein gjendannes.

- Jeg var innlagt i 15 måneder på Martina Hansens Hospital, fra jeg var seks til syv år. Deretter var det krykker, og jeg var ni år gammel før jeg lærte meg å gå på ski. Jeg hang langt etter de andre barna, men jeg hadde en far og venner som dro meg med på tur. Først et stykke inn $\mathrm{i}$ tenårene hadde jeg tatt igjen "forspranget» som mine jevnaldrende hadde.

- Det var lenge å være på sykehus uten foreldre?

- Ja, vi fikk besøk én gang i måneden. Det var et par timer med visittid, og enten kom moren eller faren min.

- Fikk dere ringe hjem?

- Nei, det gjorde vi aldri.

Min første sigarett smakte jeg som en seks år gammel pasient på Martina Hansens Hospital

Han forteller om å være et sykt barn i en helt annen tid.

- Først lå jeg på åttemannsrom, siden på firemannsrom. Mange hadde samme sykdom som meg, og det er en vanskelig sykdom å ha for aktive barn. Det er ikke smertefullt, men vi skulle ikke belaste bena. Da lyset ble slukket om kvelden, spratt vi ut på gulvet for å ha putekrig. Hvis du ble tatt flere ganger, fikk du på deg en vest som ble festet under sengen, en slags tvangstrøye. Den kunne du imidlertid klare å vri deg ut av, og ble du fersket i det, fikk du gipsbelte. Da satt du bom fast i sengen. Det var de tøffeste guttene som endte slik. En av guttene som lå i gipsbelte, fikk smuglet inn en pakke sigaretter en gang. Du kan se for deg sovesalen med åtte gutter som sender sigaretten rundt. Det ble selvfølgelig oppdaget. Overlegen holdt en tordentale neste dag. Jeg husker den godt, humrer han.

\section{Tore Steen}

Født 25. juli 1950

Cand.med., Universitetet i Bergen 1975

Distriktslege/kommunelege i Vågan 1979-91

Spesialist i samfunnsmedisin 1984

Spesialist i allmennmedisin 1988

Master of public health, Nordic School of Public Health 1996

Dr.med., Universitetet i Bergen, 2001

Assisterende fylkeslege i Vest-Agder 1994-2001

Regionslege/distriktslege/rådgiver i Botswana ca. 8 år

Smittevernoverlege i Oslo kommune 2001-

- Så min første sigarett smakte jeg som en seks år gammel pasient på Martina Hansens Hospital.

- Og nå da?

-Nå røyker jeg bare pipe på fisketur. Ingenting slår det mot mygg!

\section{Kunne ikke tegne}

- Hvorfor ble du lege?

- Min far var arkitekt. Jeg fikk alltid høre av andre at det var det jeg burde bli, men jeg kunne ikke tegne. Mattelæreren tok meg til side etter timene på gymnaset og sa flere ganger: «Steen, du må studere matematikk». Etter videregående skole var jeg et år på utveksling $\mathrm{i}$ USA, mens en god kamerat begynte ved medisinstudiet i Bergen. Han skrev begeistrede brev, hvor han reklamerte for både byen og studiet. Så ble jeg fristet til å komme etter. 
- Hva gjorde din mor?

- Hun var utdannet bibliotekar, men giftet seg og fikk barn og var hjemmeværende i 30 år. Hun fikk ti år i yrkeslivet på tampen, men det tror jeg hun var godt fornøyd med.

- Etter studiet reiste du nordover?

- Min daværende kone hadde aldri vært i Nord-Norge, og vi hadde begge lyst til å oppleve noe annet. Jeg hadde trekningsnummer fem, så vi kunne velge fritt. Det verste med Bergen var forresten ikke regnet, det var at det ikke gikk an å gå på ski.

- Det var ikke så lett å gå på ski i Kristiansand heller?

- Jo, bare et par mil inn i landet kunne vi gå på ski fra jul til påske den gang, og det gikk skitog i helgene.

Steen var i mange år distriktslege i Vågan.

- Svolvær er et fantastisk sted hvis du er glad i friluftsliv. Du kan dra på Lofothavet om formiddagen og ta en skitur på ettermiddagen.

- Du har trivdes godt både nordpå og i Afrika, er det noen fellestrekk?

- Ett fellestrekk mellom Nord-Norge og Botswana er iallfall fantastiske naturopplevelser.

- Og du likte Nord-Norge bedre enn Sørlandet, hvorfor?

- Det har flere årsaker, men her er én: Nordlendinger er rett på sak, de snakker stort sett rett fra levra. I 1994 flyttet vi en periode tilbake til Kristiansand, og der kunne det være vanskelig å komme frem til sakens kjerne. Standarduttrykket var: «Vi har det så greit så». Men så er det kanskje ikke så greit likevel. Agderfylkene har et høyt forbruk av beroligende legemidler. Jeg har lurt på om det kan ha noe med at folk bærer mye inni seg. Jeg merket det godt etter å ha bodd andre steder i 25 år.

Jeg så røntgenbildet til den første hivpasienten i Botswana, men det var ikke jeg som stilte diagnosen. Det har jeg ergret meg litt over i etterkant

Steen har vært veileder i allmennmedisin og samfunnsmedisin gjennom mange år.

- I veiledningsgruppene i samfunnsmedisin er de fleste kommuneleger, og det er mange flotte yngre kolleger som virkelig brenner for faget.

- Og hva med deg selv?

- Når jeg tenker tilbake på årene i Nord-Norge kunne jeg nok vært en mer pågående samfunnsmedisiner. Søppelhåndtering, drikkevannsforsyning - det er mange ting jeg kunne jobbet mer med. Jeg hadde en liten kampsak, jeg prøvde å få til hjelmpåbud i slalåmbakken etter å ha sett flere hodeskader. Men jeg lyktes ikke. Det var litt puslete forsøk, jeg kunne gjort mer i både den og andre saker.

\section{Gruvearbeid og tuberkulose}

- Hvorfor reiste dere til Afrika?

- Jeg og min første kone hadde til felles at vi begge var nysgjerrige og reiselystne. Noen venner vi hadde i Svolvær dro til Botswana. Etter å ha hørt dem fortelle derfra, ble vi fristet til å reise ut. Jeg søkte og fikk en jobb i Sudan, men før jeg rakk å begynne, brøt borgerkrigen løs. Så ble det Botswana i stedet. Vi var heldige og kom til en gruveby. Der var det en del infrastruktur og en god engelsk skole som barna kunne gå på.

Familien hadde med seg tre gutter. I Botswana adopterte de en jente. Senere fikk de nok en gutt. 


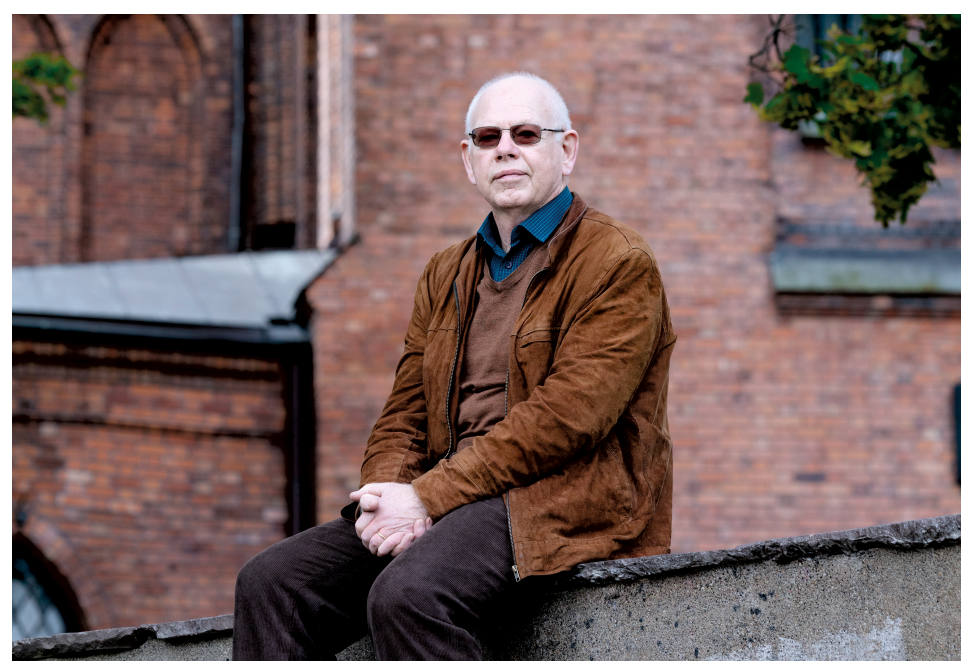

- Hva var din jobb?

- Jeg var regionslege. Det var en blanding av distriktslege og fylkeslege, men med et stort distrikt og rundt 100 ooo innbyggere. Byen vi bodde i hadde egentlig et ganske godt eget helsevesen, jeg brukte mest tid på klinikker i resten av distriktet. Jeg var den eneste legen i hele primærhelsetjenesten, som i all hovedsak ble drevet av sykepleiere. På klinikkene så jeg til utvalgte pasienter. Det var tradisjon for at regionslegene skulle ta seg av tuberkulosetilfellene. Jeg hadde bare vært der i noen få uker før overlegen fra sykehuset, en eldre inder, kom bort med noen røntgenbilder han ville diskutere. Jeg hadde knapt sett tuberkulose siden legestudiet, men man lærte jo etter hvert.

- Hva med hiv?

- Jeg så røntgenbildet til den første hivpasienten i Botswana, men det var ikke jeg som stilte diagnosen. Det har jeg ergret meg litt over i etterkant. Pasienten hadde uforklarlig feber. Overlegen på sykehuset kom bort med et røntgenbilde med lite å se på. Vi ble enige om at det kunne være tuberkulose, men det passet ikke helt. Da jeg kom tilbake i 1991, hadde hivepidemien eksplodert.

\section{Vaksiner og vaksinemotstand}

- Nå er du smittevernoverlege i Oslo. Er du bekymret for smittevern og resistensutvikling?

- Det er en kjensgjerning at det kommer nye sykdommer etter hvert, slik det var med hiv. Vi vet bare ikke hva det blir og hvordan det vil arte seg. Når det gjelder resistens, gjør vi så godt vi kan i Norge. Det blir allikevel en dråpe i havet i den store sammenhengen, sier han litt resignert.

- I Nepal, hvor jeg også har arbeidet, kan du for eksempel kjøpe bredspektret antibiotika over disk.

Jeg synes ikke det er et uforholdsmessig inngrep at alle barn skal ta vaksine mot meslinger

- Du har uttalt deg om vaksinasjon mot meslinger?

- Folkehelseinstituttet mener det skal være frivillig, mens vår helsebyråd i Oslo mener det bør være obligatorisk vaksinasjon. Jeg har etter hvert skiftet mening, og tenker at vi bør vurdere obligatorisk vaksine mot meslinger. De fleste tilfellene er barn som smittes på ferie i foreldrenes hjemland, de kan være for unge til å bli vaksinert eller de kan være uvaksinert på grunn av skeptiske foreldre. Jeg synes det er synd når barn blir alvorlig syke og det kunne vært unngått. Et vanlig argument er at foreldrene må få bestemme, men det er en god del ting foreldre ikke får lov til å velge for sine barn. Sender du ikke barna dine på skolen, kan barnevernet gripe inn. Jeg synes ikke det er et uforholdsmessig inngrep at alle barn skal ta vaksine mot meslinger.

Det er pasienthistoriene som gjør mest inntrykk. 
- Jeg husker godt et lite barn som ble svært alvorlig sykt under meslingutbruddet i Oslo i 2011. Det er slikt man ikke glemmer, men folk flest har ikke sett alvorlig syke pasienter med meslinger.

- Hva med helsepersonell?

- Jeg synes man skal forvente at helsepersonell blir vaksinert etter anbefalingene.

- Tar du influensavaksine?

- Ja. Jeg kan jo ikke være en uvaksinert smittevernoverlege, humrer han.

\section{Lottogevinst}

Steen går av med pensjon neste år.

- Er det noe du er særlig fornøyd med å ha gjort?

- Hvis jeg skal si at jeg er stolt av noe, er det nok det jeg utrettet i Botswana. I 1993 var jeg på en tuberkulosekonferanse i Mosambik. Jeg traff en lege fra Sør-Afrika som var opptatt av silikose og andre lungesykdommer hos tidligere gruvearbeidere. Arbeider du i gullgruver, er det høy risiko for å utvikle silikose, og mange menn fra Sør-Afrikas naboland har arbeidet i gullgruvene der. Min kollega mente det ville være interessant hvis noen i et naboland kunne undersøke silikoseforekomst, og vi ble enige om å få dette til. Dessuten hadde SørAfrika en yrkesskadeerstatningsordning, og den var lite kjent utenfor landegrensene. I en landsby med mange tidligere gruvearbeidere unders $\emptyset$ kte vi over 300 menn med kliniske tester, lungerøntgen og spirometri.

I prosjektet samarbeidet vi blant annet med universitetet i Cape Town, og vi hjalp pasienter med funn med å søke erstatning. Undersøkelsen resulterte i flere artikler, og noen av pasientene fikk erstatning. For de som bodde i hytter uten strøm og vann, var dette som å vinne i lotto. I Botswana fulgte man dessuten veldig bra opp. Det ble etablert en nasjonal ordning for å bistå de som hadde jobbet i gruver og fått skadevirkninger.

Afrika har fått stor betydning for Steen. Hans nåværende kone Grace er fra Kenya, og hun hadde fire døtre fra før. I leiligheten på Sinsen er det stadig overnattingsgjester og en internasjonal meny. Hvert kvartal er han og kona i en bokklubb sammen med tre andre familier som også har jobbet i Botswana.

- Vi leser bare afrikansk litteratur. Noen av bøkene ville jeg nok ellers aldri ha lest, men det gir helt unike leseopplevelser.

Han har fortsatt en dragning sørover.

- Det å lese de bøkene, det er nesten som å være tilbake igjen.

Publisert: 14. november 2019. Tidsskr Nor Legeforen. DOI:10.4045/tidsskr.19.0613

(C) Tidsskrift for Den norske legeforening 2020. Lastet ned fra tidsskriftet.no 